\title{
Proinsulin processing in the diabetic Goto-Kakizaki rat
}

\author{
P C Guest, S M Abdel-Halim ${ }^{1}$, D J Gross ${ }^{2}$, A Clark ${ }^{3}$, V Poitout ${ }^{4}$, \\ R Amaria ${ }^{5}$, C-G Ostenson ${ }^{1}$ and J C Hutton ${ }^{5}$
}

\author{
Department of Clinical Biochemistry, Addenbrooke's Hospital, Hills Road, Cambridge CB2 2QR, UK \\ ${ }^{1}$ Endocrine and Diabetes Unit, Department of Molecular Medicine, Karolinska Hospital, Stockholm S17176, Sweden \\ ${ }^{2}$ Department of Endocrinology and Metabolism, Hadassah University Hospital and the Hebrew University-Hadassah Medical School, Jerusalem 91120, Israel \\ ${ }^{3}$ Diabetes Research Laboratories, Radcliffe Infirmary, Woodstock Road, Oxford OX2 6HE, UK \\ ${ }^{4}$ Pacific Northwest Research Institute, 720 Broadway, Seattle, Washington 98122, USA \\ ${ }^{5}$ Barbara Davis Center for Childhood Diabetes, University of Colorado Health Sciences Center, 4200 East 9th Avenue, Denver, Colorado 80262, USA \\ (Requests for offprints should be addressed to J C Hutton; Email: john.hutton@uchsc.edu)
}

\begin{abstract}
The biosynthesis and processing of proinsulin was investigated in the diabetic Goto-Kakizaki (GK) rat. Immunofluorescence microscopy comparing GK and Wistar control rat pancreata revealed marked changes in the distribution of $\alpha$-cells and pronounced $\beta$-cell heterogeneity in the expression patterns of insulin, prohormone convertases PC1, PC2, carboxypeptidase E (CPE) and the PC-binding proteins $7 \mathrm{~B} 2$ and ProSAAS. Western blot analyses of isolated islets revealed little difference in PC1 and CPE expression but PC2 immunoreactivity was markedly lower in the GK islets. The processing of the PC2-dependent substrate chromogranin A was reduced as evidenced by the appearance of intermediates. No differ-
\end{abstract}

ences were seen in the biosynthesis and post-translational modification of PC1, PC2 or CPE following incubation of islets in $16.7 \mathrm{mM}$ glucose, but incubation in $3.3 \mathrm{mM}$ glucose resulted in decreased PC2 biosynthesis in the GK islets. The rates of biosynthesis, processing and secretion of newly synthesized (pro)insulin were comparable. Circulating insulin immunoreactivity in both Wistar and GK rats was predominantly insulin 1 and 2 in the expected ratios with no (pro)insulin evident. Thus, the marked changes in islet morphology and PC2 expression did not impact the rate or extent of proinsulin processing either in vitro or in vivo in this experimental model.

Journal of Endocrinology (2002) 175, 637-647

\section{Introduction}

Proinsulin and its conversion intermediates (des 31,32 proinsulin and des 64,65 proinsulin) make up around $10-15 \%$ of the total insulin immunoreactivity in the circulation of healthy humans (Ward et al. 1987, Clark et al. 1992, Reaven et al. 1993). They are secreted in a regulated manner from the pancreatic $\beta$-cells of islets where they make up around $1-2 \%$ islet insulin immunoreactivity (Hou et al. 1997). They accumulate in the circulation due to their longer half-lives $\left(t_{1 / 2}\right)$ relative to insulin, but have only weak hypoglycemic activity (Creemers et al. 1998). Elevation of circulating proinsulin and the processing intermediates is observed in a number of pathophysiological situations including the prodrome of type 1 diabetes (Heaton et al. 1988), mild type 2 diabetes (Clark et al. 1992), glucose-intolerant states (Davies et al. 1993), pancreatic duct obstruction, thyroid disease (Beer et al. 1989) and insulin resistance induced by corticosteroids (Ward et al. 1987). More pronounced proinsulinemia is associated with genetic mutations in the proinsulin molecule (Nanjo et al. 1987, Roder et al. 1996), proinsulin-processing enzyme defects (Naggert et al. 1995, Jackson et al. 1997, Furuta et al. 1998) and pancreatic adenomas (Cohen et al. 1986). (Proinsulinemia is defined here as conditions where either the proinsulin molecule or any of the common processing intermediates (split 32,33 proinsulin, des 31,32 proinsulin, split 65,66 proinsulin, des 64,65 proinsulin) are elevated more than 2 -fold.) The origin of hyperproinsulinemia in diabetes has variously been attributed to deficiency in $\beta$-cell prohormone convertase (PC) activity (Rhodes \& Alarcon 1994), changes in the intragranular processing environment $(\mathrm{pH}$ and $\mathrm{Ca}$ changes) (Furukawa et al. 1999) or asynchrony between stimulation of secretion and biosynthesis (Bollheimer et al. 1998). Incomplete processing could equally arise from increased secretory granule turnover as a direct consequence of the increased demands imposed by peripheral insulin resistance or decreased functional $\beta$-cell mass (Alarcon et al. 1995, Gadot et al. 1995, Seaquist et al. 1996, Laedtke et al. 2000). Another possibility could be regulation of the prohormone endopeptidases PC1 and PC2 by endogenous chaperonins or protease inhibitors in the pancreatic $\beta$-cell such as PC-derived propeptides (Fugere 
et al. 2002) or PC inhibitors 7B2 and ProSAAS (Benjannet et al. 1995, Feng et al. 2001).

There are few experimental data that shed light upon these possible molecular and cell biological defects. Rodent islets, on which most insulin secretion studies are performed, have two non-allelic insulin gene products that are expressed at different levels and processed at different rates. The determination of proinsulin and the major intermediates in humans is facilitated by the availability of two-site immunometric assays (Heaton et al. 1988, Davies et al. 1993). However, these cannot be applied to rodent (pro)insulins and most data have been obtained by laborious RIA of samples separated by HPLC (Leahy et al. 1991, Gadot et al. 1995).

In the present study, we have used the Goto-Kakizaki (GK) rat model of type 2 diabetes (Goto et al. 1988) to investigate the expression of the prohormone convertases PC1, PC2 and carboxypeptidase E (CPE) and the PC inhibitors 7B2 and ProSAAS and co-related this to proinsulin processing in vitro and in vivo. We found changes in islet morphology consistent with $\beta$-cell degranulation and marked alterations in the steady-state level and biosynthesis of PC2. Such changes, however, appear to have little impact on the processing of proinsulin in the rat.

\section{Materials and Methods}

\section{Animals and tissue preparation}

Guidelines for the use and care of laboratory animals were followed at the institutions where the animals were housed. GK and Wistar control animals of 9-10 weeks of age were used to model the early stages of diabetes when body weight is normal and $\beta$-cell mass and density is largely preserved (Ostenson et al. 1993). Animals were fed freely and food withdrawn $4 \mathrm{~h}$ prior to killing. Islets were prepared by collagenase digestion (Guest et al. 1989) and cultured overnight in Dulbecco's modified Eagle's medium (Gibco) containing $8.3 \mathrm{mM}$ glucose.

\section{Histology}

Pancreas pieces from 8- and 12-week-old animals were fixed in $10 \%$ formalin, paraffin embedded and prepared for immunofluorescence microscopy by conventional procedures (Pow \& Clark 1990). Sections were incubated with a guinea pig polyclonal antibody to insulin (1:200) or mouse monoclonal antibody to glucagon (Sigma, 1:500) in combination with a polyclonal rabbit antibody to one of the following; PC1 (Lindberg (Louisiana State University) $\mathrm{NH}_{2}$-terminal 1:200), PC2 (Creemers (University of Leuven) 1:200), CPE (Hutton 1:100) or ProSAAS (Lindberg recombinant 1:50). 7B2 (Creemers 102 1:200) antibody was combined with either the above insulin antisera or rabbit anti-glucagon (Hutton 1:200) (Guest et al. 1989, 1992, Creemers et al. 1996, Sayah et al. 2001).
Binding of the primary antibodies was detected with appropriate CY-2-, CY-3- or rhodamine-conjugated species-specific anti-IgGs (Jackson Laboratories, Bar Harbor, ME, USA) in the second layer. All procedures on GK and Wistar sections were performed in parallel. Preimmune sera and preabsorption controls were performed in each case (data not shown). Images were captured with a Coolsnap HQ digital camera (Photometrics, New York, NY, USA) on a Nikon FXA microphot fluorescence microscope using Intelligent Imaging System (Denver, CO, USA) software.

\section{Western blot analysis}

For analysis of PC1, PC2 and CPE, groups of 100 freshly isolated islets were collected into SDS-PAGE loading buffer containing $65 \mathrm{mM}$ dithiothreitol, heated for $5 \mathrm{~min}$ at $100{ }^{\circ} \mathrm{C}$ and electrophoresed on gels polymerized from $12.5 \%$ acrylamide $0.08 \% \mathrm{~N}, \mathrm{~N}^{\prime}$-bisacrylamide in an SDSTris-glycine buffer system (Hutton et al. 1990). Proteins were transferred electrophoretically onto PVDF membranes (Amersham) and subjected to Western blot analysis using antisera to PC1 (rabbit 1:1000), PC2 (rabbit 1:1000), CPE (rabbit 1:1000) and chromogranin A (1:2000) and visualized by chemiluminescence (Amersham kit). All primary antibodies were generated in-house to recombinant proteins.

\section{Biosynthetic radiolabeling}

Groups of 100 islets were preincubated for $30 \mathrm{~min}$ in $100 \mu \mathrm{l}$ Krebs bicarbonate buffer containing 3.3 or $16.7 \mathrm{mM}$ glucose at $37^{\circ} \mathrm{C}$ in $1.5 \mathrm{ml}$ capacity microcentrifuge tubes. They were then recovered by centrifugation for $10 \mathrm{~s}$ at $800 \mathrm{~g}$ (Microcentaur microcentifuge; MSE) and resuspended in $100 \mu \mathrm{l}$ of the same pre-warmed medium containing $150 \mu \mathrm{Ci}\left[{ }^{35} \mathrm{~S}\right]$ methionine (Amersham) and incubated for $30 \mathrm{~min}$ at $37^{\circ} \mathrm{C}$ (Hutton et al. 1990). Pulse-chase experiments were performed using a $30 \mathrm{~min}$ radiolabeling in $16.7 \mathrm{mM}$ glucose followed by resuspension of the islets for $45 \mathrm{~min}$ or $3 \mathrm{~h}$ in pre-warmed medium without radioisotope but containing $2 \mathrm{mM}$ methionine and either 3.3 or $16.7 \mathrm{mM}$ glucose. The islets and their media were then separated and the islets sonicated for $15 \mathrm{~s}$ at $25 \mathrm{~W}$ (MSE Sonifier, Crawley, UK) in $200 \mu \mathrm{l}$ lysis buffer (25 $\mathrm{mM} \mathrm{Na}_{2} \mathrm{~B}_{4} \mathrm{O}_{7}$ (pH 9), 3\% BSA, 1\% Tween-20, $1 \mathrm{mM}$ phenylmethanesulfonyl fluoride, $0.1 \mathrm{mM} \mathrm{E}-64$, $1 \mathrm{mM}$ EDTA and $0 \cdot 1 \% \mathrm{NaN}_{3}$ ). The lysates were centrifuged for $5 \mathrm{~min}$ at $13000 \mathrm{~g}$ and the supernatants retained for immunoprecipitation.

\section{Immunoprecipitation}

Islet lysates or media were incubated for $1 \mathrm{~h}$ at room temperature with $20 \mu \mathrm{l} 100 \mathrm{mg} / \mathrm{ml}$ suspension of Cowanstrain Staphylococcus aureus cells and then centrifuged for 
$5 \mathrm{~min}$ at $13000 \mathrm{~g}$. The supernatants were subjected to serial immunoprecipitation with a monoclonal insulin antibody (3B7) and then antisera against PC1, PC2 and CPE using established methodology (Hutton et al. 1990). The eluted proteins were electrophoresed on gels polymerized from either $7 \cdot 5 \%$ acrylamide $0 \cdot 08 \% N, N^{\prime}$ bisacrylamide in a Tris- $\mathrm{HCl}$-urea buffer system (insulin) (Hutton et al. 1990) or by standard Laemmli SDS-PAGE on $12 \cdot 5 \%$ acrylamide $0.08 \% \mathrm{~N}, \mathrm{~N}^{\prime}$-bisacrylamide gels in a Tris-glycine buffer system (PC1, PC2 and CPE) followed by fluorography and densitometric analysis (Guest et al. 1989).

\section{Circulating proinsulin}

Sera were pooled from three or four overnight-fasted rats and insulin-related peptides partially purified using C18 Sep-Pak cartridges (Waters \& Associates, Milford, MA, USA) (Cohen et al. 1986). The eluted peptides were resolved by reverse-phase HPLC using a C-18 (0.5 $\mu \mathrm{m})$ $250 \times 4.6 \mathrm{~mm}$ Synchropac column (Hewlett-Packard, Boeblingen, Germany) on a 1050 Hewlett-Packard HPLC system. The column was eluted at $1 \mathrm{ml} / \mathrm{min}$ under isocratic conditions for 25 min with $30.5 \%$ acetonitrile in $0 \cdot 2 \%$ trifluoroacetic acid and then with a gradient of acetonitrile to $35 \cdot 5 \%$ over an additional $55 \mathrm{~min}$. Fractions $(1 \mathrm{ml})$ were collected into tubes containing $0.1 \mathrm{ml} 0 \cdot 1 \%$ $\mathrm{BSA}$, freeze-dried and reconstituted in $1 \mathrm{ml}$ RIA buffer (PBS with $0 \cdot 1 \%$ BSA). The elution positions of the rat 1 and 2 insulin-related peptides were determined with $\mathrm{L}-\left[4,5-{ }^{3} \mathrm{H}\right]$ leucine- and $\left[{ }^{35} \mathrm{~S}\right]$ methionine-radiolabeled standards. Insulin-related peptides in the eluate were measured by RIA using rat insulin (Novo-Nordisk, Bagsvaerd, Denmark) as a standard. Porcine ${ }^{125}$ I-insulin was obtained from Diagnostic Products Corp. (Los Angeles, CA, USA) and guinea-pig anti-porcine insulin from Linco Research Inc. (St Charles, MO, USA). Separation of bound and free hormone was performed using goat antiguinea pig IgG serum and precipitation of the immune complex using $4 \%(\mathrm{w} / \mathrm{v})$ polyethylene glycol.

\section{Results}

\section{Immunohistochemistry}

At the point of killing, the GK rats were comparable to controls in body weight (Table 1) and they showed no signs of obesity or dehydration. They were markedly hyperglycemic but had comparable circulating insulin levels (total insulin immunoreactivity).

The yield and size of isolated islets was comparable for each group (100-150/rat) and the protein content was comparable (data not shown). The borders of GK islets, however, were irregular and they appeared more vascularized as revealed by their visible content of red blood cells. Immunofluorescence microscopy (Fig. 1) revealed
Table 1 Animal data (means \pm S.E.M.)

\begin{tabular}{lcc} 
& $\begin{array}{c}\text { Wistar } \\
(n=13)\end{array}$ & $\begin{array}{l}\text { GK } \\
(n=16)\end{array}$ \\
\cline { 2 - 2 } & $221 \pm 2$ & $231 \pm 4$ \\
Body weight $(\mathrm{g})$ & $8 \cdot 7 \pm 0 \cdot 7$ & $18 \cdot 6 \pm 1 \cdot 6$ \\
Blood glucose $(\mathrm{mmol} / \mathrm{l})$ & $64 \pm 5$ & $65 \pm 6$ \\
Serum insulin $(\mu \mathrm{U} / \mathrm{ml})$ & & \\
\hline
\end{tabular}

that the proportion of $\beta$-cells to non- $\beta$-cells appeared normal in islets of GK animals but that the insulin immunoreactivity in the $\beta$-cell population was more variable than in control Wistar islets. Glucagon-positive cells were as prominent in GK islets as in Wistar islets; however, their spatial distribution was markedly altered in the GK animals. The peripheral localization of glucagonpositive cells in Wistar islets was replaced in GK animals with a more random distribution throughout the core of GK islets.

PC1 immunoreactivity was expressed at a higher level in $\beta$-cells than non- $\beta$-cells in both Wistar control and GK rats and there was little, if any, overlap in PC1 and glucagon immunoreactivity (Fig. 1A). There was an uneven distribution of PC1 among insulin-positive cells of the GK rat and an apparent correlation between the level of expression of insulin and PC1 within the same cell across the entire population of $\beta$-cells.

PC2 was broadly distributed in $\beta$ - and $\alpha$-cells in both GK and Wistar islets and double-labeling experiments again showed a general correlation between the intensity of PC2 and insulin immunofluorescence in $\beta$-cells and a similar correlation between PC2 and glucagon immunofluorescence in $\alpha$-cells (Fig. 1A).

CPE was found in $\beta$ - and $\alpha$-cells (Fig. 1B, double labeling with insulin not shown) with no obvious difference in distribution between $\alpha$ - and $\beta$-cells between GK and Wistar animals. The chaperonin/PC2 inhibitor 7B2 was present in both $\alpha$ - and $\beta$-cells and the immunofluorescence intensity was similar in both cells with no obvious changes in cellular association in Wistar and GK animals. The ProSAAS molecule, which is a putative regulator of PC1 activity, was found in both $\alpha$ - and $\beta$-cells in both Wistar and GK rats. Within the $\beta$-cell population there was again a variable distribution of CPE, 7B2 and ProSAAS from cell to cell and, as in the case of PC1 and PC2, a general correlation between the expression of each marker and insulin (data not shown).

\section{Western blot analysis of PCs and chromogranin $A$}

The steady-state levels and maturation of the proprotein converting enzymes was assessed by Western blot analyses using equal numbers of islets per lane (Fig. 2). The endopeptidase PC1 appeared as the processed COOHtruncated $66 \mathrm{kDa}$ form in both GK and Wistar islets with 


\section{A.}
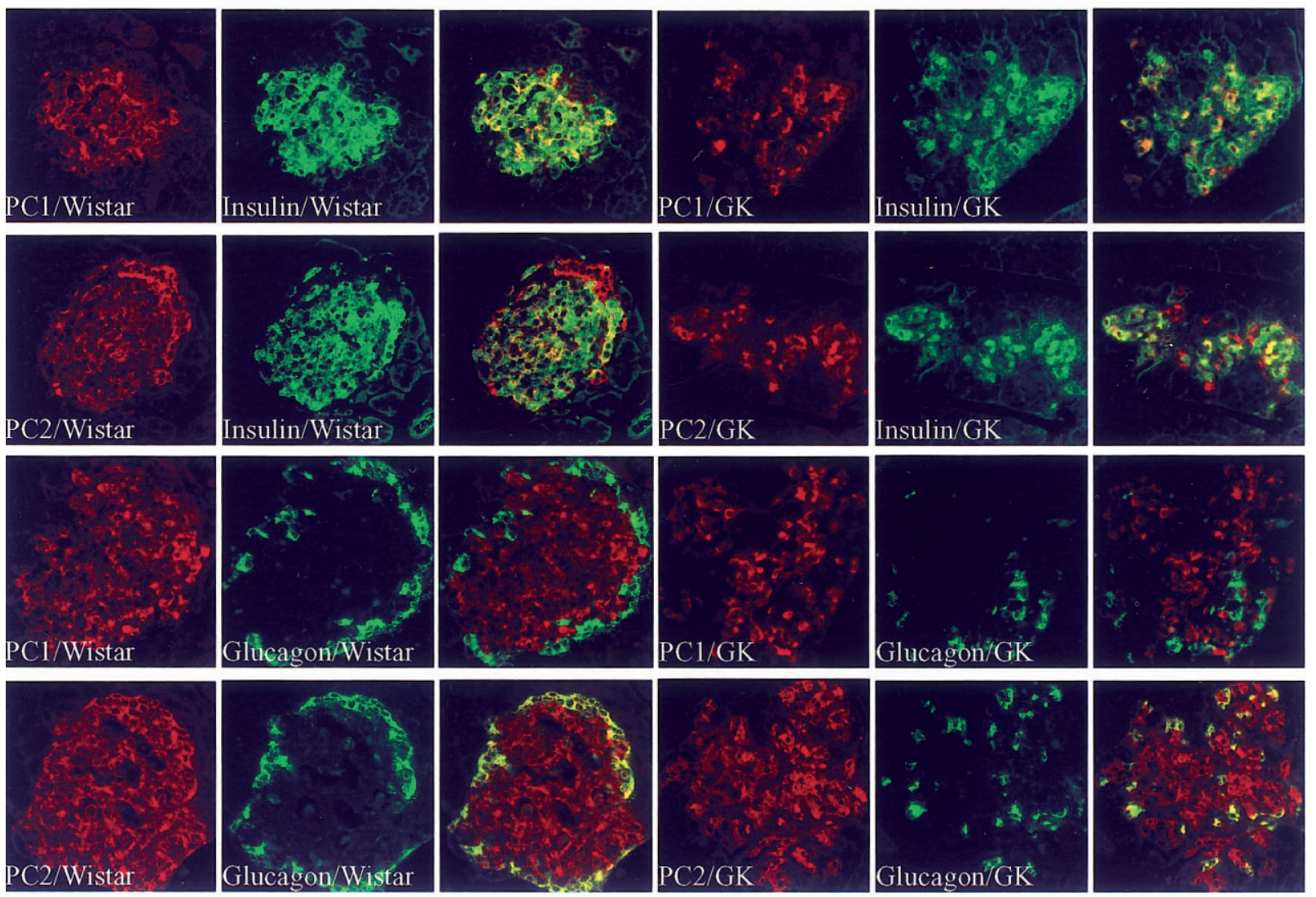

B.

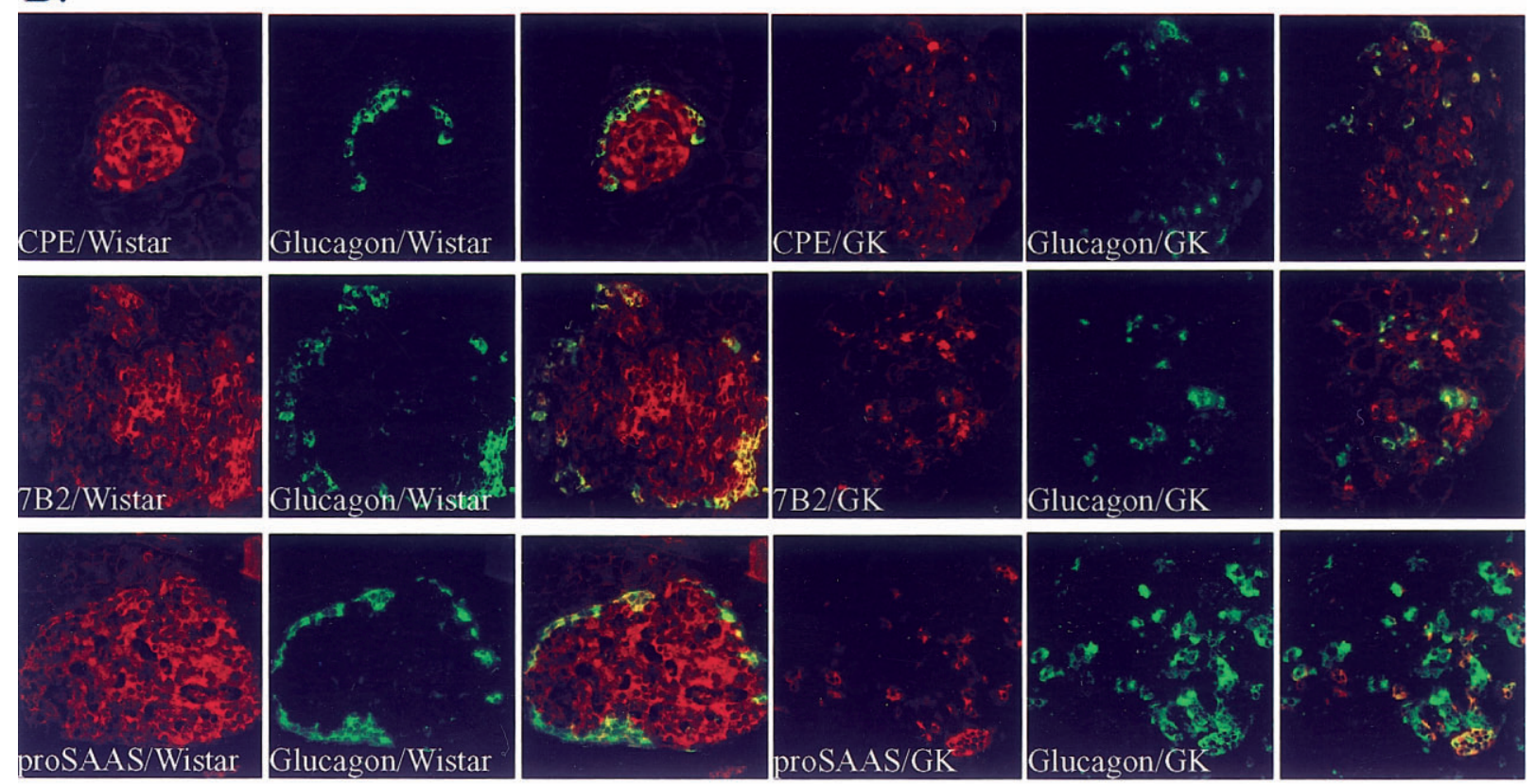




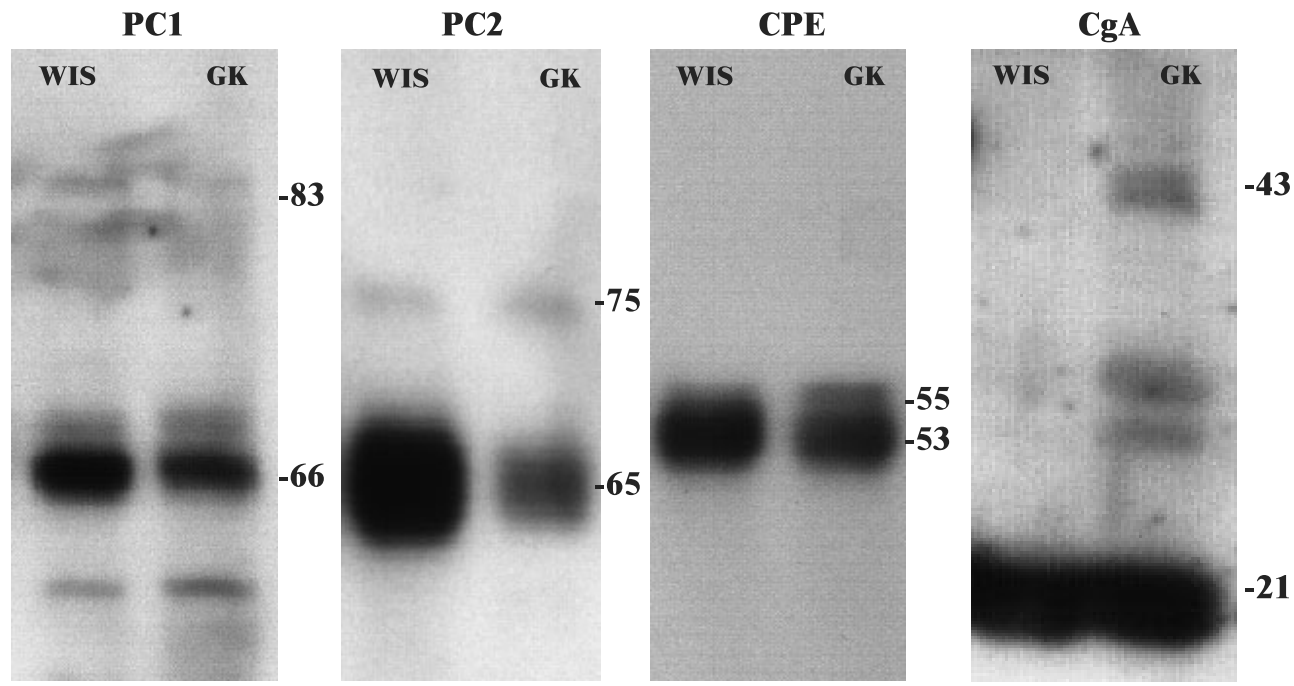

Figure 2 Western blot analyses of prohormone convertases. Western blot analyses of PC1, PC2, CPE and chromogranin A (CgA) were performed on SDS-Laemmli gels with batches of 100 islets. Similar results were obtained in three separate experiments using islets pooled from four animals.

no significant difference in the overall level of expression in GK animals. The PC2 endoprotease appeared as the mature $65 \mathrm{kDa}$ form in islets from both GK and control rats but was present at lower levels in the GK islets. CPE expression was similar in both animal groups although there was proportionately more of the unprocessed $55 \mathrm{kDa}$ precursor form in GK islets. Chromogranin A, which is converted in the pancreatic $\beta$-cell by PC2 to the $21 \mathrm{kDa}$ peptide betagranin (Arden et al. 1994), was found in the GK rat islets to include larger molecular forms, presumably processing intermediates (Fig. 2). Western blot analyses with anti-insulin antibodies detected abundant insulin but negligible proinsulin or proinsulin intermediates in either GK or Wistar animals (data not shown).

\section{Biosynthetic radiolabeling}

Pulse-chase radiolabeling experiments coupled with immunoprecipitation analysis showed that the biosynthesis of PC1 in GK islets followed a similar pattern in the Wistar controls (Fig. 3A). Incorporation of radioactivity was stimulated markedly by glucose compared with the response of total proteins (2- to 3-fold increase in trichloroacetic acid-precipitable radioactivity (Guest et al. 1989)). PC1 underwent post-translational modification including early glycosylation and carbohydrate trimming (increase from $83 \mathrm{kDa}$ to $87 \mathrm{kDa}$ and back) and subsequent $\mathrm{COOH}$-terminal proteolysis (decrease from $83 \mathrm{kDa}$ to $66 \mathrm{kDa}$ ) with similar kinetics. CPE labeling and posttranslational processing were similar in islets of both animal strains but, in contrast, the synthesis of PC2, which is normally glucose-insensitive, appeared to be responsive to glucose in GK rats but not in Wistar controls. The incorporation of radioactivity into PC2 was similar in both animal strains at $16.7 \mathrm{mM}$ glucose but at $3.3 \mathrm{mM}$ GK islets show considerably less incorporation of $\left[{ }^{35} \mathrm{~S}\right]$ methionine into PC2 than Wistar islets. The post-translational processing of the $75 \mathrm{kDa}$ precursor to the $65 \mathrm{kDa}$ mature form over the pulse-chase protocol proceeded with similar kinetics and no major differences were detectable over the $3 \mathrm{~h}$ time course. The observed changes in molecular sizes are in accord with previous studies (Creemers et al. 1998).

No major differences were observed in the biosynthesis and processing of proinsulin between the GK and Wistar islets (Fig. 3B). Islets incorporated similar levels of $\left[{ }^{35} \mathrm{~S}\right]$ methionine under basal conditions, elevation of glucose increased incorporation to a similar extent and the conversion of proinsulin to insulin proceeded with similar kinetics via the conversion intermediates. Under the conditions used, only rat proinsulin 2 is labeled as

Figure 1 Immunohistochemistry of insulin in isolated islets and PC1 and PC2 in pancreatic sections of GK and Wistar animals. Indirect immunofluorescence microscopy was performed on paraffin-embedded pancreas sections using combinations of an antibody to either insulin or glucagon alongside antibodies from another species directed to other antigens. Secondary antibodies conjugated to CY-2 (green channel) and either CY-3 or rhodamine (red channel) were used in the second layer. Images of each fluorophore are displayed in pseudocolor and the merged images are shown in each case. (A) The most striking differences between the GK and Wistar animals were the heterogeneity of expression of insulin, PC1 and PC2 and more dispersed distribution of $\alpha$-cells in the GK islets. The exclusion of PC1 from $\alpha$-cells was apparent in both control and diabetic animals. (B) CPE, 7B2 and ProSAAS were expressed in both $\alpha$ - and $\beta$-cells. Like insulin (A), they showed a more heterogeneous expression in $\beta$-cells in the GK animals. 
A.

PC1

83-

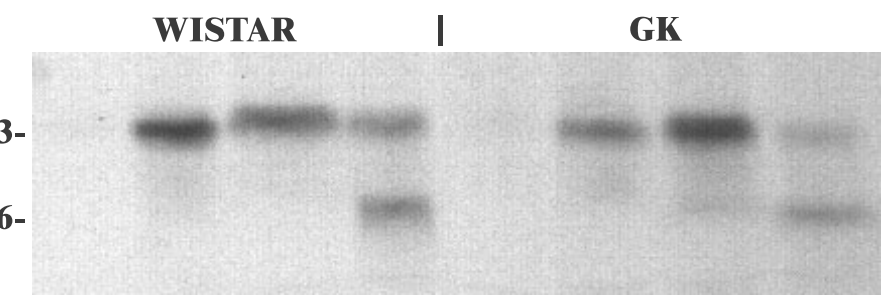

PC2

75-

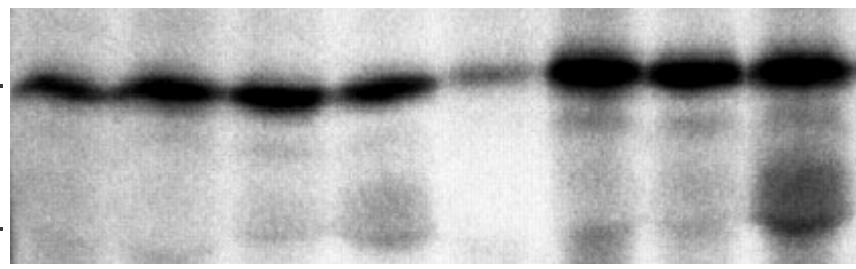

CPE

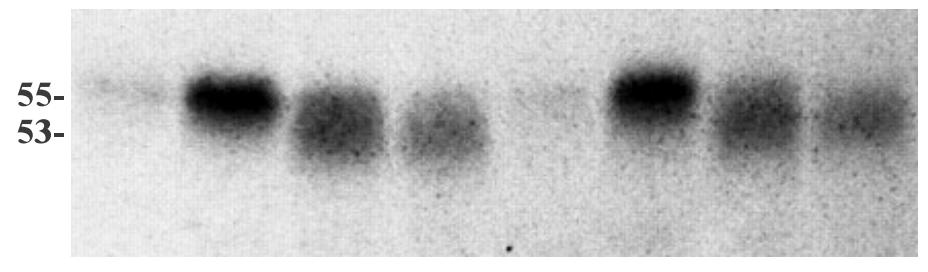

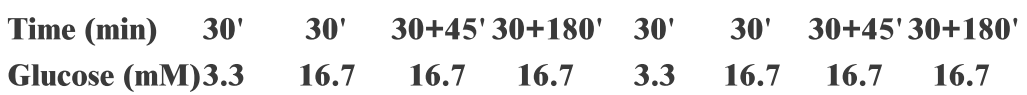

B.

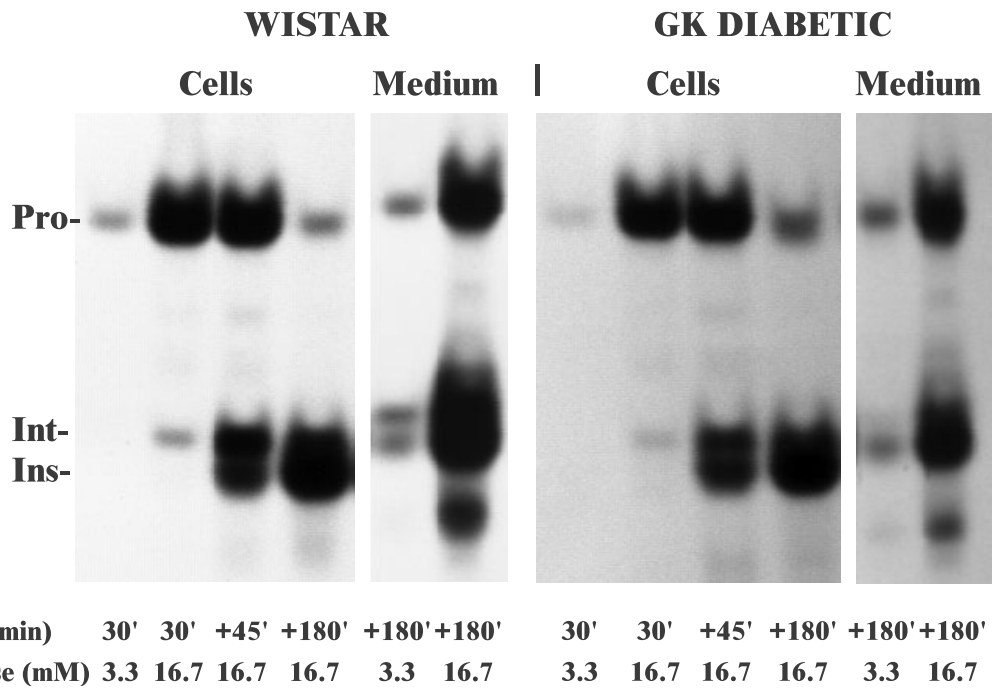

Figure 3 Biosynthetic radiolabeling of PCs and proinsulin. Islets in batches of 100 were preincubated for 30 min and then labeled with ${ }^{35} \mathrm{~S}$ S methionine for $30 \mathrm{~min}$ in the presence of $3.3 \mathrm{mM}$ glucose (track 1) or $16.7 \mathrm{mM}$ glucose (track 2) to assess the affects of glucose on biosynthesis (see Methods section). For pulse-chase experiments, islets were radiolabeled as above in $16.7 \mathrm{mM}$ glucose and then chased in medium containing $2 \mathrm{mM}$ methionine (no radiolabel) and either 3.3 or $16.7 \mathrm{mM}$ glucose for either 45 or 180 min.

(A) Immunoprecipitates of the cellular forms of the PCs (100 islet equivalents/lane) were analyzed on SDS-Laemmli gels.

(B) Immunoprecipitates of the cellular (20 islet equivalents/lane) and medium (100 islet equivalents/lane) forms of labeled (pro)insulin were analyzed on Tris-glycine-urea gels. Similar results were obtained in three separate experiments using batches of islets pooled from four animals. 
proinsulin 1 does not contain a methionine residue. Labeled insulin peptides accumulated in the medium under conditions of glucose stimulation in both GK and Wistar rat islets. Previous studies have shown that the release of newly synthesized insulin peptides can be triggered approximately $30 \mathrm{~min}$ after labeling when they are first delivered to the secretory granule (Creemers et al. 1998). The composition of secreted insulin-related peptides is initially dominated by proinsulin and at later times by insulin, a reflection of the proteolytic maturation of the granule cargo. The composition of the peptides in the medium determined in these experiments thus effectively integrates the changes in cellular composition of the peptides over the $180 \mathrm{~min}$ chase period. The observation that the composition of the immunoprecipitated peptides was similar in both GK and Wistar islets suggests that both the intracellular conversion of proinsulin and release of the insulin-related peptides followed similar kinetics.

\section{Measurements of circulating (pro)insulin levels}

Determination of the composition of circulating insulin peptides by a combined HPLC/RIA technique showed major immunoreactive peaks corresponding to insulin 1 and insulin 2 with lesser amounts of a component that co-elutes with insulin 2 which has undergone oxidation of its single Met residue either in vivo or during sample preparation. These molecular forms corresponded to $92 \%$ (Wistar) and 93\% (GK) of the total immunoreactivity recovered from the HPLC gradient (two assays from seven animals). The levels of proinsulin or proinsulin-processing intermediates in the circulation of both the Wistar and GK rats were less than $2 \%$ of the insulin immunoreactivity (Fig. 4), a situation in marked contrast to human where levels in the range of 10-30\% are recorded (Jackson et al. 1997). The insulin 1 to insulin 2 ratio was similar in both animal groups (2.58 vs $2 \cdot 56)$.

\section{Discussion}

The GK rat is a non-obese insulin-resistant model (Bisbis et al. 1993) of type 2 diabetes involving multiple genetic loci (Galli et al. 1996, Gauguier et al. 1996) that was produced by selective inbreeding for a hyperglycemic trait (Goto et al. 1988). At the level of the islet, changes in glucose metabolism (Tsuura et al. 1993, Ling et al. 1998) or cAMP generation (Abdel-Halim et al. 1998) are associated with a secretory defect that is more pronounced in vivo and in perfused pancreas (Portha et al. 1991) than in static incubations (Portha et al. 1991, Hughes et al. 1994). The present studies have used animals from the Stockholm colony (Abdel-Halim et al. 1994), which have been shown to have preserved $\beta$-cell density (Guenifi et al. 1995) and to have less-pronounced morphological and diabetic phenotypes than the Paris colony (Portha et al. 1991, Movassat et al. 1997).

We focused on the biosynthesis and post-translational processing of proinsulin and the proinsulin-processing enzymes in these animals, events that are acutely regulated by glucose at the level of protein translation and potentially influenced by a complex series of post-Golgi sorting and membrane-trafficking events (Creemers et al. 1998). Initial immunocytochemical analysis provided a survey of the molecular components of the proinsulin-processing machinery that potentially affect the production of the active hormone at the cellular level. Dramatic differences between GK and Wistar rats were observed in the distribution of $\alpha$-cells throughout the islet and heterogeneity of the $\beta$-cell population in the GK animals with respect to their expression of insulin. The heterogeneity in insulin expression appeared to be paralleled by heterogeneity in the expression of the other components of the processing machinery, namely the enzymes PC1, PC2 and their respective inhibitors $7 \mathrm{~B} 2$ and ProSAAS and the exopeptidase CPE. All the proteins in question are localized to the secretory granule and the observed changes are consistent with cell-to-cell differences in granulation, yet the overall insulin content per islet was not altered in these animals (C-G Östenson, V Poitout \& J C Hutton, unpublished observations). The heterogeneity is possibly the result of the differences in the thresholds of individual $\beta$-cells for glucose-activated metabolism (Heimberg et al. 1993, Bennett et al. 1996), granule exocytosis and insulin biosynthesis (Kiekens et al. 1992), or a feedback mechanism that interconnects these processes. It is conceivable that changes in paracrine relationships between the $\beta$-cell and $\alpha$-cell could play a role given the marked changes in $\alpha$-cell distribution that characterize the islets of the GK rat and other diabetic models (Movassat et al. 1997).

The finding that proinsulin biosynthesis and processing of proinsulin appeared normal in 9-week-old GK rats was remarkable in the face of such striking morphological changes. The results agree with previous studies (Giroix et al. 1993, Nagamatsu et al. 1999) and suggest that the depletion of secreted constituents in $\beta$-cells does not arise from a failure to recognize glucose as an activator of prohormone biosynthesis and granule biogenesis. Rather it points to an inability of the $\beta$-cell population as a whole to meet the demands upon insulin secretion imposed by chronic hyperglycemia in vivo. Although circulating insulin levels did not differ between GK rats and their Wistar controls, they were inappropriate for the level of glycemia indicative of insulin resistance or either a secretory defect and/or reduction in functional $\beta$-cell mass. The evident degranulation (Fig. 1) and previous studies showing reduced $\beta$-cell mass from a very early age (Serradas et al. 1998) suggest that the latter may be more important. Given that the defect in the GK $\beta$-cell lies at the level of cyclic nucleotide generation and stimulus-secretion coupling (Portha et al. 1991, Abdel-Halim et al. 1998), it is 

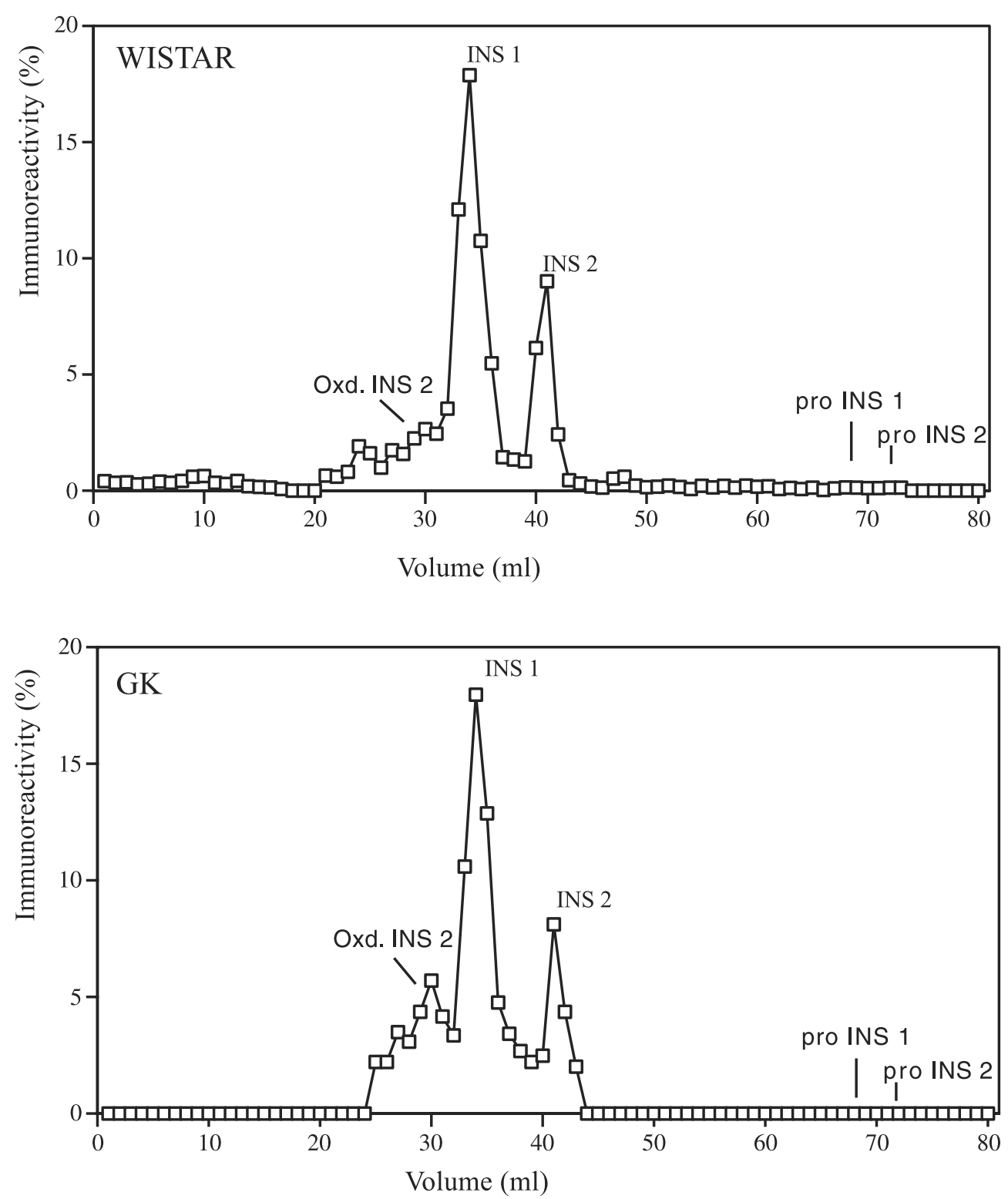

Figure 4 HPLC analysis of circulating immunoreactive forms of insulin in Wistar and GK rats. The position of elution of insulin 1 and insulin 2 are indicated. The processing intermediates elute between the insulin and proinsulin molecules. Oxd. INS $2=$ oxidized insulin 2. Similar results were obtained in two separate experiments using serum pooled from either three or four animals.

likely that there may not be an impairment in stimulusbiosynthesis coupling since it is not thought to depend on this second messenger. Under such circumstances, the extent of proinsulin processing within the $\beta$-cell might actually be more complete since immature granules would not be exocytosed. Defective exocytosis, on the other hand, would prevent the positive feedback of insulin or other secreted products on $\beta$-cell transcriptional activity and replication/antiapoptosis (Burks \& White 2001), which in the longer term would affect the secretory capacity of individual $\beta$-cells and pancreatic $\beta$-cell mass.

The major biochemical changes that were observed in the GK rat appeared to be in the prohormone-processing enzyme PC2. Steady-state levels of islet PC2 in GK islets were reduced relative to Wistar islets yet rates of biosynthesis and processing at high glucose in vitro appeared normal. It appeared that PC2 biosynthesis at low glucose concentrations was diminished. Since it is evident that 
PC2 is more concentrated in $\alpha$-cells of normal islets (Fig. $1 \mathrm{~A})$, the question arises as to whether the changes in the steady-state levels and biosynthesis of PC2 in the GK animals truly reflect changes occurring in the $\beta$-cell. Islets from another diabetic model, the $o b / o b$ mouse, like the GK rat, show a glucose-stimulated PC2 biosynthetic response that is not evident in control strains (Martin et al. 1994). Since cultured Min6 $\beta$-cells also show glucose-stimulated PC2 biosynthesis (Skelly et al. 1996), it has been argued that glucose-stimulated PC2 biosynthesis is an intrinsic property of the $\beta$-cell that is unmasked in $o b / o b$ mice by the massive expansion of $\beta$-cell mass and the loss of $\alpha$-cells. The glucagon content of GK islets is not markedly changed, although GK islets appear similar to $o b / o b$ islets in that the $\alpha$-cell distribution is altered (Baetens et al. 1978). It appears more likely in the present instance that there is a reduced biosynthesis of PC2 in the diabetic GK rat islets at lower glucose concentrations. The reduced islet content of PC2 revealed by Western blotting could reflect this phenomenon operating in vivo and/or an effect of granule depletion. Granule constituents with a slow rate of maturation such as PC2 ( $\mathrm{t}_{1 / 2}$ of conversion $2-3 \mathrm{~h}$ vs 5-10 min for PC1) are most likely to be affected by degranulation.

From studies in rats rendered hyperglycemic by repeated glucose injection or by $90 \%$ pancreactectomy (Leahy et al. 1991), it has been inferred that $\beta$-cell granule exhaustion is the primary cause of alterations in circulating proinsulin in man. Similar conclusions have been reached by direct measurement of the circulating proinsulin levels in the spontaneously diabetic sand rat Psammomys obesus (Gadot et al. 1995). In each case, a very marked decrease in insulin content and degranulation was observed and elevated proinsulin secretion was seen to be the consequence of the relative immaturity of the granule population. In humans, a decrease in $\beta$-cell mass produced by hemipancreatectomy (Seaquist et al. 1996) induces a 5- to 6-fold increase in circulating proinsulin without major excursions in plasma glucose. Likewise low-dose streptozotocin in a non-human primate can cause hyperproinsulinemia without hyperglycemia (Kahn et al. 1992). Suppression of endogenous insulin secretion in mildly diabetic humans in vivo can restore circulating proinsulin/ insulin ratios and pulsatile release within $24 \mathrm{~h}$ (Laedtke et al. 2000), which again fits with the concept that granule maturity is a key determinant of the release of proinsulin and particularly the major intermediate, des 31,32 proinsulin.

The circulating levels of proinsulin or proinsulin conversion intermediates in the GK diabetic rat did not model the situation in diabetic humans. The failure to observe any proinsulin or processing intermediates in the normal Wistar rat also contrasts with the situation found in healthy human subjects. The simplest explanation for these differences is that proinsulin conversion is more efficient or more extensive in the rodent than in human islets $\left(t_{1 / 2}\right.$ of conversion 40 vs $100 \mathrm{~min}$ (Sizonenko et al. 1993)). There are important sequence differences at both the B-chain/ C-peptide and C-peptide/A-chain cleavage sites between the human and rodent proinsulins (Sizonenko \& Halban 1991). The processing of human proinsulin occurs at sites marked by the sequence Lys-Thr-Arg-Arg and Leu-GlnLys-Arg, which are cleaved by the endoproteases PC1 and PC2 respectively (Davidson et al. 1987). These enzymes work sequentially and thus little cleavage of the C-peptide/A-chain junction by PC2 occurs in the absence of prior cleavage at the B-chain/C-peptide junction by PC1 (Jackson et al. 1997). By contrast, processing of rat proinsulin 2 (as studied in the present radiolabeling experiments) occurs at sites marked by Met-Ser-Arg-Arg (B-chain/C-peptide junction) and Arg-Gln-Lys-Arg (Cpeptide/A-chain junction), both of which can be cleaved by PC1 alone (Vollenweider et al. 1995). The presence of a P-4 Arg at the C-peptide/A-chain junction is critical in this regard and probably also makes rat proinsulin a better substrate for PC2. Changes in the steady-state level and biosynthesis of PC2 in GK diabetic animals of the magnitude observed might therefore have little impact on proinsulin conversion in the rat. In the PC2 knockout mouse, only minor impairment in islet proinsulin processing occurs (identical B-chain/C-peptide and similar C-peptide/A-chain junctions to rat except mouse insulin 2 lacks the P4 Arg) (Furuta et al. 1998). The heterozygote (PC2 +/-) mouse, which could have a comparable defect to the GK rat (50\% reduction in PC2 expression), is reportedly normal. The changes which were observed nevertheless may still be sufficient to impact rates of proprotein conversion as evidenced by the accumulation of intermediate forms of chromogranin $\mathrm{A} \mathrm{NH}_{2}$-terminal processing, a reaction that is catalyzed by PC2 (Arden et al. 1994). The chromogranin A intermediates that appear in the GK islets (Fig. 2) were identical in size to intermediate forms seen in the islets of PC2 null mice (J C Hutton \& D F Steiner, unpublished observations).

Equivalent changes in PC2 expression in human diabetic islets might nevertheless impede conversion of des 31,32 proinsulin to insulin and lead to elevation in the circulation of that intermediate (Hou et al. 1997). In this context it is notable that it is des 31,32 proinsulin more than proinsulin or the des 64,65 intermediate that contributes to the increase of (pro)insulin immunoreactivity in diabetes (Clark et al. 1992). It would be of interest to observe how a GK rat bearing a human proinsulin transgene would behave in this context.

\section{Acknowledgements}

These studies were supported by grants from the Juvenile Diabetes Foundation International, the UK Wellcome Trust, the Swedish Diabetes Association and the Swedish Medical Research Council (00034) (C-G O) and Barbara 
Davis Center Diabetes and Endocrinology Research Center (P30 DK57516). Carrie John is thanked for assistance in preparing the manuscript.

\section{References}

Abdel-Halim SM, Guenifi A, Luthman H, Grill V, Efendic S \& Ostenson CG 1994 Impact of diabetic inheritance on glucose tolerance and insulin secretion in spontaneously diabetic GK-Wistar rats. Diabetes 43 281-288.

Abdel-Halim SM, Guenifi A, He B, Yang B, Mustafa M, Hojeberg B, Hillert J, Bakhiet M \& Efendic S 1998 Mutations in the promoter of adenylyl cyclase (AC)-III gene, overexpression of AC-III mRNA, and enhanced cAMP generation in islets from the spontaneously diabetic GK rat model of type 2 diabetes. Diabetes $\mathbf{4 7}$ 498-504.

Alarcon C, Leahy JL, Schuppin GT \& Rhodes CJ 1995 Increased secretory demand rather than a defect in the proinsulin conversion mechanism causes hyperproinsulinemia in a glucose-infusion rat model of non-insulin-dependent diabetes mellitus. Journal of Clinical Investigation 95 1032-1039.

Arden SD, Rutherford NG, Guest PC, Curry WJ, Bailyes EM, Johnston CF \& Hutton JC 1994 The post-translational processing of chromogranin $\mathrm{A}$ in the pancreatic islet: involvement of the eukaryote subtilisin PC2. Biochemical Journal 298 521-528.

Baetens D, Stefan Y, Ravazzola M, Malaisse-Lagae F, Coleman DL \& Orci L 1978 Alteration of islet cell populations in spontaneously diabetic mice. Diabetes 27 1-7.

Beer SF, Parr JH, Temple RC \& Hales CN 1989 The effect of thyroid disease on proinsulin and C-peptide levels. Clinical Endocrinology 30 379-383.

Benjannet S, Savaria D, Chretien M \& Seidah NG 1995 7B2 is a specific intracellular binding protein of the prohormone convertase PC2. Journal of Neurochemistry 64 2303-2311.

Bennett BD, Jetton TL, Ying G, Magnuson MA \& Piston DW 1996 Quantitative subcellular imaging of glucose metabolism within intact pancreatic islets. Journal of Biological Chemistry 271 3647-3651.

Bisbis S, Bailbe D, Tormo MA, Picarel-Blanchot F, Derouet M, Simon J \& Portha B 1993 Insulin resistance in the GK rat: decreased receptor number but normal kinase activity in liver. American Journal of Physiology 265 E807-E813.

Bollheimer LC, Skelly RH, Chester MW, McGarry JD \& Rhodes CJ 1998 Chronic exposure to free fatty acid reduces pancreatic beta cell insulin content by increasing basal insulin secretion that is not compensated for by a corresponding increase in proinsulin biosynthesis translation. Journal of Clinical Investigation 101 1094-1101.

Burks DJ \& White MF 2001 IRS proteins and beta-cell function. Diabetes 50 (Suppl 1) S140-S145.

Clark PM, Levy JC, Cox L, Burnett M, Turner RC \& Hales CN 1992 Immunoradiometric assay of insulin, intact proinsulin and 32-33 split proinsulin and radioimmunoassay of insulin in diet-treated type 2 (non-insulin-dependent) diabetic subjects. Diabetologia 35 469-474.

Cohen RM, Given BD, Licinio-Paixao J, Provow SA, Rue PA, Frank BH, Root MA, Polonsky KS, Tager HS \& Rubenstein AH 1986 Proinsulin radioimmunoassay in the evaluation of insulinomas and familial hyperproinsulinemia. Metabolism 35 1137-1146.

Creemers JW, Usac EF, Bright NA, Van de Loo JW, Jansen E, Van de Ven WJ \& Hutton JC 1996 Identification of a transferable sorting domain for the regulated pathway in the prohormone convertase PC2. Journal of Biological Chemistry 271 25284-25291.

Creemers JW, Jackson RS \& Hutton JC 1998 Molecular and cellular regulation of prohormone processing. Seminars in Cell and Developmental Biology 9 3-10.
Davidson HW, Peshavaria M \& Hutton JC 1987 Proteolytic conversion of proinsulin into insulin. Identification of a $\mathrm{Ca}^{2+}$-dependent acidic endopeptidase in isolated insulin-secretory granules. Biochemical Journal 246 279-286.

Davies MJ, Rayman G, Gray IP, Day JL \& Hales CN 1993 Insulin deficiency and increased plasma concentration of intact and 32/33 split proinsulin in subjects with impaired glucose tolerance. Diabetic Medicine 10 313-320.

Feng Y, Reznik SE \& Fricker LD 2001 Distribution of PROSAAS-derived peptides in rat neuroendocrine tissues. Neuroscience 105 469-478.

Fugere M, Limperis PC, Beaulieu-Audy V, Gagnon F, Lavigne P, Klarskov K, Leduc R \& Day R 2002 Inhibitory potency and specificity of subtilase-like pro-protein convertase (SPC) prodomains. Journal of Biological Chemistry 277 7648-7656.

Furukawa H, Carroll RJ, Swift HH \& Steiner DF 1999 Long-term elevation of free fatty acids leads to delayed processing of proinsulin and prohormone convertases 2 and 3 in the pancreatic beta-cell line MIN6. Diabetes 48 1395-1401.

Furuta M, Carroll R, Martin S, Swift HH, Ravazzola M, Orci L \& Steiner DF 1998 Incomplete processing of proinsulin to insulin accompanied by elevation of Des-31,32 proinsulin intermediates in islets of mice lacking active PC2. Journal of Biological Chemistry 273 3431-3437.

Gadot M, Ariav Y, Cerasi E, Kaiser N \& Gross DJ 1995 Hyperproinsulinemia in the diabetic Psammomys obesus is a result of increased secretory demand on the beta-cell. Endocrinology 136 4218-4223.

Galli J, Li LS, Glaser A, Ostenson CG, Jiao H, Fakhrai-Rad H, Jacob HJ, Lander ES \& Luthman H 1996 Genetic analysis of non-insulin dependent diabetes mellitus in the GK rat. Nature Genetics 12 $31-37$.

Gauguier D, Froguel P, Parent V, Bernard C, Bihoreau MT, Portha B, James MR, Penicaud L, Lathrop M \& Ktorza A 1996 Chromosomal mapping of genetic loci associated with non-insulin dependent diabetes in the GK rat. Nature Genetics 12 38-43.

Giroix MH, Vesco L \& Portha B 1993 Functional and metabolic perturbations in isolated pancreatic islets from the GK rat, a genetic model of noninsulin-dependent diabetes. Endocrinology 132 815-822.

Goto Y, Suzuki K, Ono T, Sasaki M \& Toyota T 1988 Development of diabetes in the non-obese NIDDM rat (GK rat). Advances in Experimental Medicine and Biology 246 29-31.

Guenifi A, Abdel-Halim SM, Hoog A, Falkmer S \& Ostenson CG 1995 Preserved beta-cell density in the endocrine pancreas of young, spontaneously diabetic Goto-Kakizaki (GK) rats. Pancreas 10 148-153.

Guest PC, Rhodes CJ \& Hutton JC 1989 Regulation of the biosynthesis of insulin-secretory-granule proteins. Co-ordinate translational control is exerted on some, but not all, granule matrix constituents. Biochemical Journal 257 431-437.

Guest PC, Arden SD, Bennett DL, Clark A, Rutherford NG \& Hutton JC 1992 The post-translational processing and intracellular sorting of PC2 in the islets of Langerhans. Journal of Biological Chemistry 267 22401-22406.

Heaton DA, Millward BA, Gray IP, Tun Y, Hales CN, Pyke DA \& Leslie RD 1988 Increased proinsulin levels as an early indicator of B-cell dysfunction in non-diabetic twins of type 1 (insulindependent) diabetic patients. Diabetologia 31 182-184.

Heimberg H, De Vos A, Vandercammen A, Van Schaftingen E, Pipeleers D \& Schuit F 1993 Heterogeneity in glucose sensitivity among pancreatic beta-cells is correlated to differences in glucose phosphorylation rather than glucose transport. EMBO Journal 12 2873-2879.

Hou X, Ling Z, Zambre Y, Foriers A, Houssa P, Deberg M, Sodoyez JC, Hales CN, Van der Auwera BJ, Pipeleers D et al 1997 
Proinsulin and its conversion intermediates in human pancreas and isolated islet tissue: kinetics and steady-state analysis. Pancreas $\mathbf{1 5}$ 113-121.

Hughes SJ, Suzuki K \& Goto Y 1994 The role of islet secretory function in the development of diabetes in the GK Wistar rat. Diabetologia 37 863-870.

Hutton JC, Bailyes EM, Rhodes CJ \& Guest PC 1990 Regulation of the biosynthesis and processing of polypeptide hormones. In Peptide Hormone Secretion: a Practical Approach, pp 309-336. Eds J Hutton \& K Siddle. Oxford: IRL Press.

Jackson RS, Creemers JW, Ohagi S, Raffin-Sanson ML, Sanders L, Montague CT, Hutton JC \& O'Rahilly S 1997 Obesity and impaired prohormone processing associated with mutations in the human prohormone convertase 1 gene [see comments]. Nature Genetics 16 303-306.

Kahn SE, McCulloch DK, Schwartz MW, Palmer JP \& Porte D Jr 1992 Effect of insulin resistance and hyperglycemia on proinsulin release in a primate model of diabetes mellitus. Journal of Clinical Endocrinology and Metabolism 74 192-197.

Kiekens R, In't Veld P, Mahler T, Schuit F, Van De Winkel M \& Pipeleers D 1992 Differences in glucose recognition by individual rat pancreatic B cells are associated with intercellular differences in glucose-induced biosynthetic activity. Journal of Clinical Investigation 89 117-125.

Laedtke T, Kjems L, Porksen N, Schmitz O, Veldhuis J, Kao PC \& Butler PC 2000 Overnight inhibition of insulin secretion restores pulsatility and proinsulin/insulin ratio in type 2 diabetes. American Journal of Physiology. Endocrinology and Metabolism 279 E520-E528.

Leahy JL, Halban PA \& Weir GC 1991 Relative hypersecretion of proinsulin in rat model of NIDDM. Diabetes 40 985-989.

Ling ZC, Efendic S, Wibom R, Abdel-Halim SM, Ostenson CG, Landau BR \& Khan A 1998 Glucose metabolism in Goto-Kakizaki rat islets. Endocrinology 139 2670-2675.

Martin SK, Carroll R, Benig M \& Steiner DF 1994 Regulation by glucose of the biosynthesis of PC2, PC3 and proinsulin in $(o b / o b)$ mouse islets of Langerhans. FEBS Letters 356 279-282.

Movassat J, Saulnier C, Serradas P \& Portha B 1997 Impaired development of pancreatic beta-cell mass is a primary event during the progression to diabetes in the GK rat. Diabetologia 40 916-925.

Nagamatsu S, Nakamichi Y, Yamamura C, Matsushima S, Watanabe T, Ozawa S, Furukawa H \& Ishida H 1999 Decreased expression of t-SNARE, syntaxin 1, and SNAP-25 in pancreatic beta-cells is involved in impaired insulin secretion from diabetic GK rat islets: restoration of decreased t-SNARE proteins improves impaired insulin secretion. Diabetes 48 2367-2373.

Naggert JK, Fricker LD, Varlamov O, Nishina PM, Rouille Y, Steiner DF, Carroll RJ, Paigen BJ \& Leiter EH 1995 Hyperproinsulinaemia in obese fat/fat mice associated with a carboxypeptidase E mutation which reduces enzyme activity. Nature Genetics 10 135-142.

Nanjo K, Miyano M, Kondo M, Sanke T, Nishimura S, Miyamura K, Inouye K, Given BD, Chan SJ, Polonsky KS et al. 1987 Insulin Wakayama: familial mutant insulin syndrome in Japan. Diabetologia $3087-92$.

Ostenson CG, Khan A, Abdel-Halim SM, Guenifi A, Suzuki K, Goto Y \& Efendic S 1993 Abnormal insulin secretion and glucose metabolism in pancreatic islets from the spontaneously diabetic GK rat. Diabetologia 36 3-8.
Portha B, Serradas P, Bailbe D, Suzuki K, Goto Y \& Giroix MH 1991 Beta-cell insensitivity to glucose in the GK rat, a spontaneous nonobese model for type II diabetes. Diabetes 40 486-491.

Pow DV \& Clark A 1990 Localization of peptide hormones. In Peptide Hormone Secretion: a Practical Approach, pp 189-210. Eds J Hutton \& K Siddle. Oxford: IRL Press.

Reaven GM, Chen YD, Hollenbeck CB, Sheu WH, Ostrega D \& Polonsky KS 1993 Plasma insulin, C-peptide, and proinsulin concentrations in obese and nonobese individuals with varying degrees of glucose tolerance. Journal of Clinical Endocrinology and Metabolism 76 44-48.

Rhodes CJ \& Alarcon C 1994 What beta-cell defect could lead to hyperproinsulinemia in NIDDM? Some clues from recent advances made in understanding the proinsulin-processing mechanism. Diabetes 43 511-517.

Roder ME, Vissing H \& Nauck MA 1996 Hyperproinsulinemia in a three-generation Caucasian family due to mutant proinsulin (Arg65-His) not associated with impaired glucose tolerance: the contribution of mutant proinsulin to insulin bioactivity. Journal of Clinical Endocrinology and Metabolism 81 1634-1640.

Sayah M, Fortenberry Y, Cameron A \& Lindberg I 2001 Tissue distribution and processing of proSAAS by proprotein convertases. Journal of Neurochemistry 76 1833-1841.

Seaquist ER, Kahn SE, Clark PM, Hales CN, Porte D Jr \& Robertson RP 1996 Hyperproinsulinemia is associated with increased beta cell demand after hemipancreatectomy in humans. Journal of Clinical Investigation 97 455-460.

Serradas P, Gangnerau MN, Giroix MH, Saulnier C \& Portha B 1998 Impaired pancreatic beta cell function in the fetal GK rat. Impact of diabetic inheritance. Journal of Clinical Investigation 101 899-904.

Sizonenko SV \& Halban PA 1991 Differential rates of conversion of rat proinsulins I and II. Evidence for slow cleavage at the B-chain/C-peptide junction of proinsulin II. Biochemical Journal 278 621-625.

Sizonenko S, Irminger JC, Buhler L, Deng S, Morel P \& Halban PA 1993 Kinetics of proinsulin conversion in human islets. Diabetes 42 933-936.

Skelly RH, Schuppin GT, Ishihara H, Oka Y \& Rhodes CJ 1996 Glucose-regulated translational control of proinsulin biosynthesis with that of the proinsulin endopeptidases PC2 and PC3 in the insulin-producing MIN6 cell line. Diabetes 45 37-43.

Tsuura Y, Ishida H, Okamoto Y, Kato S, Sakamoto K, Horie M, Ikeda H, Okada Y \& Seino Y 1993 Glucose sensitivity of ATP-sensitive $\mathrm{K}^{+}$channels is impaired in beta-cells of the GK rat. A new genetic model of NIDDM. Diabetes 42 1446-1453.

Vollenweider F, Kaufmann J, Irminger JC \& Halban PA 1995 Processing of proinsulin by furin, PC2, and PC3 in (co) transfected COS (monkey kidney) cells. Diabetes 44 1075-1080.

Ward WK, LaCava EC, Paquette TL, Beard JC, Wallum BJ \& Porte D Jr 1987 Disproportionate elevation of immunoreactive proinsulin in type 2 (non-insulin-dependent) diabetes mellitus and in experimental insulin resistance. Diabetologia 30 698-702.

Received 8 June 2002

Accepted 8 August 2002 